\title{
Bilateral, locked, recurrent anterior shoulder dislocation: case report
}

\author{
İki taraflı, kilitli, tekrarlayan, ön omuz çıkığı: Olgu sunumu
}

\author{
Selim Şanel, MD., Savaş Şencan, MD., ${ }^{2}$ Ali Öçgüder, MD., ${ }^{1}$ Can Solakoğlu, MD. ${ }^{3}$ \\ 'Department of Orthopedics and Traumatology, Mareşal Çakmak Military Hospital, Erzurum, Turkey \\ ${ }^{2}$ Department of Physical Therapy and Rehabilitation, Mareşal Çakmak Military Hospital, Erzurum, Turkey \\ ${ }^{3}$ Department of Orthopedics and Traumatology, Medical Faculty of Maltepe University, İstanbul, Turkey
}

\begin{abstract}
Bilateral anterior dislocation of the shoulder is a rare condition. Most of the cases are seen as posterior dislocations which generally occur during diffuse tonic-clonic contractions of epileptic seizures or after being exposed to strong electric shock. In this article, we report a 21-year-old epileptic patient who had severe bilateral shoulder pain and joint restriction. Diagnoses of bilateral, locked, anterior shoulder dislocation and Hill-Sachs lesions were made with shoulder X-rays and computed tomography. Arthroscopic Bankart repair and remplissage technique were applied in surgical treatment of both shoulders. Posterior dislocations of shoulder usually occur during epileptic seizures but anterior dislocations are rare in the literature. This may lead to delay in diagnosis. Computed tomography scan may be helpful in making diagnosis in uncertain patients. It should not be forgotten that recurrent anterior dislocations may be seen in epileptic patients. Such dislocations should be followed up regularly and instability must be treated to prevent excessive damage to the shoulder.
\end{abstract}

Key words: Epileptic seizure; shoulder dislocation; shoulder joint/ surgery.

Shoulder dislocation accounts for $85 \%$ of all joint dislocations. ${ }^{[1]}$ However, bilateral shoulder joint dislocation is rare. ${ }^{[2,3]}$ Majority of these are posterior dislocations following grand mal seizures or electrical accidents. ${ }^{[4]}$ Anterior dislocations generally occur after traumas. ${ }^{[5]}$ In patients with seizures, glenohumeral joint may dislocate posteriorly. ${ }^{[6]}$ Computed tomography can easily detect the direction of dislocations and any Hill-Sachs lesion while giving an opinion for the treatment modality. ${ }^{[7]}$ Hill-Sachs lesions are more prone to glenohumeral
$\ddot{O} Z$

Omzun iki taraflı ön çıkığı nadir bir durumdur. Birçok olgu genellikle epileptik atakların difüz tonik-klonik kasılmaları esnasında veya güçlü elektrik şokuna maruz kaldıktan sonra ortaya çıkan arka çıkık olarak görülür. $\mathrm{Bu}$ yazıda iki taraflı şiddetli omuz ağrısı ve eklem kısitlılığı olan 21 yaşında bir epileptik hasta sunuldu. İki taraflı, kilitli, ön omuz çıkı̆̆ 1 ve Hill-Sachs lezyonları tanıları omuz grafileri ve bilgisayarlı tomografi ile konuldu. Her iki omzun cerrahi tedavisinde artroskopik Bankart tamiri ve remplissage tekniği uygulandı. Omzun arka çıkıkları sıklıkla epileptik ataklarda oluşur fakat ön çıkıklar literatürde nadirdir. Bu, tanıda gecikmeye neden olabilir. Şüpheli hastalarda bilgisayarlı tomografi incelemesi tanı konulmasına yardımcı olabilir. Epileptik hastalarda tekrarlayan ön çıkıkların görülebileceği unutulmamalıdır. Omuza aşırı hasarı önlemek için bu çıkıklar düzenli takip edilmeli ve instabilite tedavi edilmelidir.

Anahtar sözcükler: Epileptik nöbet; omuz çıkı̆̆ı; omuz eklemi/ cerrahi.

joint instability in patients with seizures. Although many anatomical and non-anatomical reconstruction techniques have been introduced, redislocation rates are still high. ${ }^{[7]}$

The patient in this case report gave consent for this article to be published in Joint Diseases and Related Surgery and related publications.

\section{CASE REPORT}

A 21-year-old male patient admitted to emergency department with shoulder ache and immobility.

- Received: December 31, 2013 Accepted: April 28, 2014

- Correspondence: Selim Şanel, MD. Maltepe Üniversitesi Tıp Fakültesi Ortopedi ve Travmatoloji Anabilim Dalı, 34844 Maltepe, İstanbul, Turkey. Tel: +90 532 - 4548989 Fax: +90 216 - 4429682 e-mail: sesanel@hotmail.com 


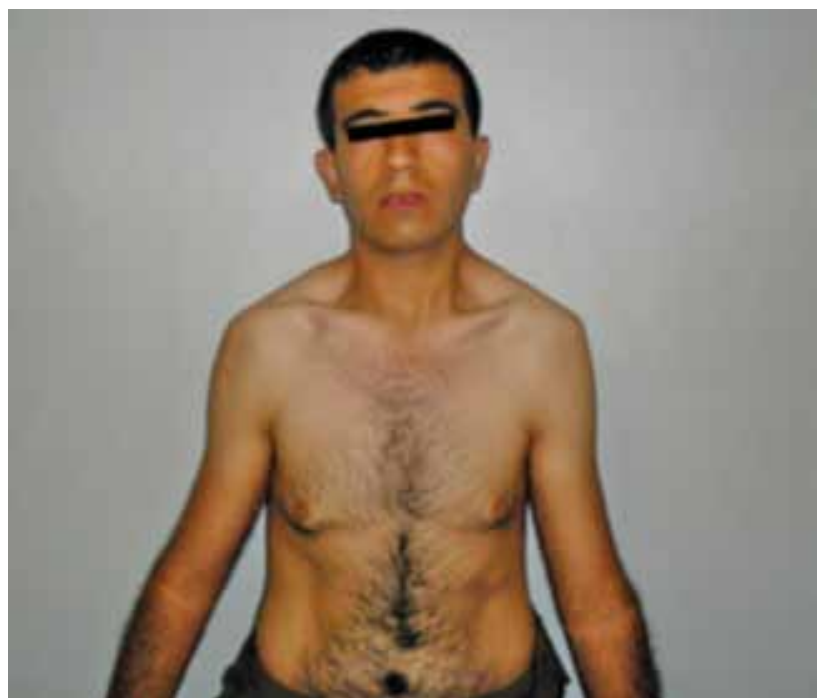

Figure 1. Loss of deltoid prominance in both shoulders.

Just before his complaints appeared, grand mal epileptic attack was reported with a history of longstanding anti epileptic treatment period. Patient had two bilateral shoulder dislocations in his history. In physical examination, shoulder joints were in abduction and external rotation. Deltoid muscles were flat just beneath acromion with anterior bulge (Figure 1). Vascular and neurological examinations were normal. X-Ray findings revealed anterior dislocation in both shoulder joints (Figure 2). Computed tomography showed bilateral Hill-Sachs lesion (Figure 3). The case was an acute bilateral anterior shoulder dislocation which occurred during epileptic seizure. Closed reduction by Kocher maneuver was performed under general anesthesia after five hours of acute dislocation. ${ }^{[8]}$ Both arms were rested in arm slings. Bankart repair and remplissage technique were carried out in arthroscopic fashion under general anesthesia to prevent recurrent shoulder joint instability (Figure 4). While right

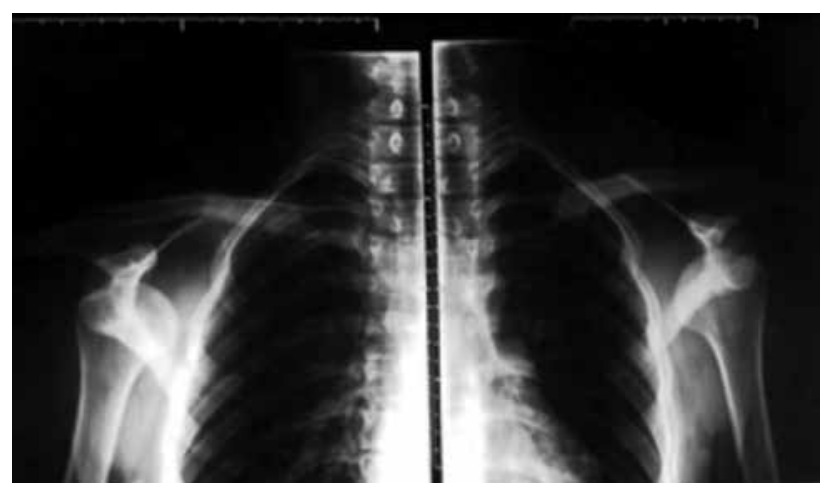

Figure 2. X-ray of both shoulders revealing anterior dislocation.

shoulder was operated two days after closed reduction, left shoulder was operated four weeks after closed reduction. Active abduction, external or internal rotations were not permitted for four weeks after the operation. Patient was given sling for two weeks (Sleep in immobilizer for 2-4 weeks) and began active hand/elbow range of motion exercises and hand gripping at first day of the operation three times daily. Passive and gentle active-assisted range of motion exercises were applied at first two weeks postoperatively. ${ }^{[9,10]}$ After two weeks, patient was referred to a rehabilitation clinic, and followed up for 24 months without any dislocation and complication. Right shoulder limitations of $10^{\circ}$ abduction, $10^{\circ}$ flexion, $20^{\circ}$ extension, $25^{\circ}$ internal rotation and $30^{\circ}$ external rotation, left shoulder limitations of $15^{\circ}$ abduction, $10^{\circ}$ flexion, $20^{\circ}$ extension, $20^{\circ}$ internal rotation, and $35^{\circ}$ external rotation were detected.

\section{DISCUSSION}

Bilateral posterior shoulder dislocations are usually seen in epileptic patients. Bilateral anterior dislocations in shoulder joints may be seen after grand mal seizures with delayed diagnosis. The rate of delayed diagnosis in bilateral shoulder
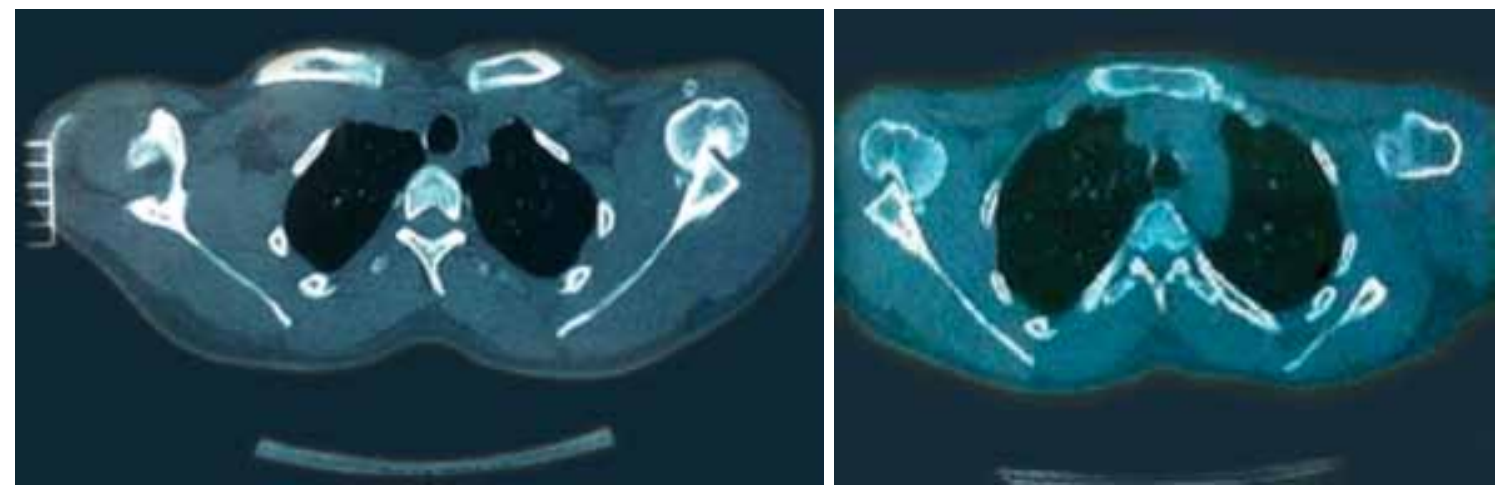

Figure 3. Computed tomography images revealing bony defects and locking in both humeral head. 

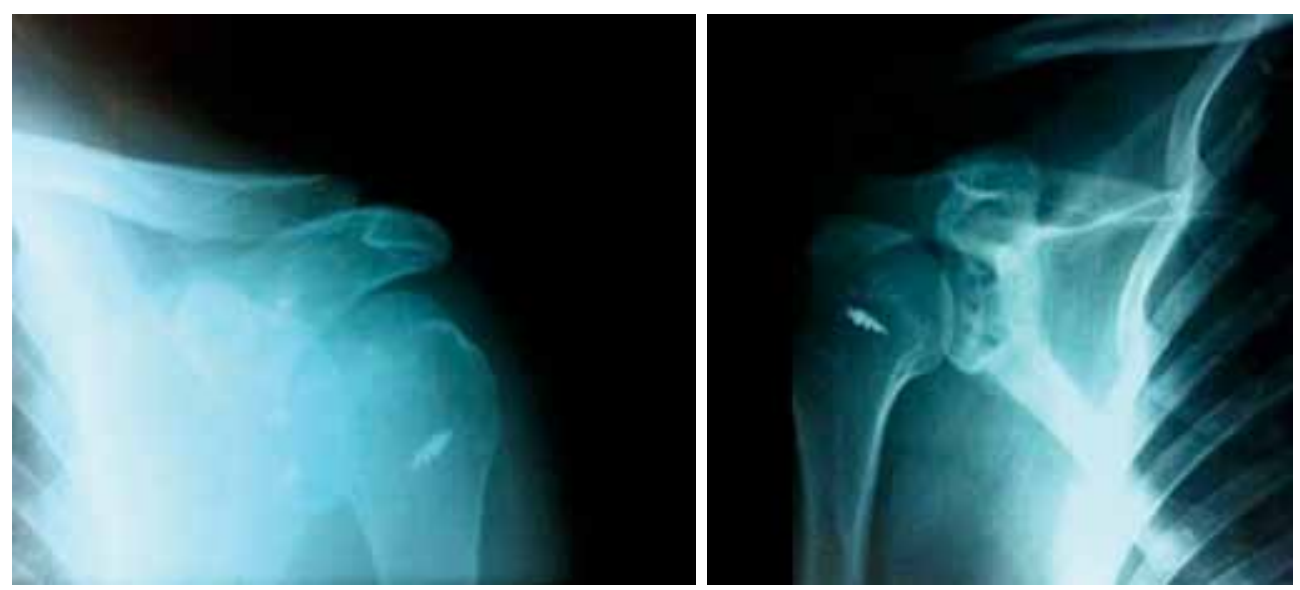

Figure 4. Postoperative X-rays of both shoulders after arthroscopic surgical repair.

dislocations is greater than $10 \% .{ }^{[7]}$ To our knowledge, in this article, we reported the first bilateral, locked, recurrent, anterior shoulder dislocation in the literature. Lasanianos and Mouzopoulos ${ }^{[1]}$ reported a 25 -year-old male with bilateral anterior shoulder dislocation. After three weeks of efforts to make a diagnosis, they performed open reduction with internal fixation technique. We applied minimally invasive arthroscopic Bankart repair in our patient.

Yanmış et al. ${ }^{[11]}$ described an alternative treatment method for unreduced chronic anterior shoulder dislocations using arthroscopy for both reduction without causing any damage to the joint and also for performing surgical repair of the labroligamentous lesion, whereas we achieved closed reduction under general anesthesia in our patient without compulsion.

We also used remplissage technique to repair Hill-Sachs lesion which may cause recurrent shoulder instability. O'connor-Read et al. ${ }^{[12]}$ reported two patients of bilateral shoulder dislocation which have been treated conservatively. As in our patient, Purchase et al. $^{[13]}$ have shown the importance of computed tomography to establish Hill-Sach's lesion well as to plan treatment modality.

As Kalkan et al. ${ }^{[14]}$ reported in their study, arthroscopic treatment of recurrent acute bilateral anterior dislocation has high success rate. On the other hand, conservative treatment results are better in first acute bilateral anterior shoulder dislocation in elderly patients. Bony defects of humeral head (HillSachs lesion) are determining factors in glenohumeral instability in patients with seizures. ${ }^{[13]}$ Bühler and Gerber ${ }^{[15]}$ reported that Hill-Sachs lesions are 12 times more common and glenoid bony fracture incidence in seizure patients suffering from glenohumeral instability is five times more common as compared to normal population. After surgical repair, redislocation rates are high which account for $50 \%$ of all surgical procedures..$^{[15,16]}$ In the literature, Connolly ${ }^{[17]}$ introduced anterior stabilization with infraspinatus tendon transfer to repair anterior dislocations. Purchase et al. ${ }^{[13]}$ used remplissage technique with arthroscopic Bankart repair in 2007. In their study, these authors have also shown that remplissage technique is an affective way to prevent recurrent anterior dislocation. We used early arthroscopic Bankart repair with remplissage technique to treat Hill-Sachs lesions and enhance patient's recovery.

Although posterior dislocations are more common in patients with seizures, anterior dislocations should also be kept in mind in epileptic patients. ${ }^{[18]}$ Anterior dislocations should be carefully examined in these patients to prevent delayed diagnosis. The use of advanced imaging modalities such as magnetic resonance imaging or computed tomography with early surgical repair may prevent future recurrent redislocations and more destructive complications in shoulder joint.

\section{Declaration of conflicting interests}

The authors declared no conflicts of interest with respect to the authorship and/or publication of this article.

\section{Funding}

The authors received no financial support for the research and/or authorship of this article.

\section{REFERENCES}

1. Lasanianos N, Mouzopoulos G. An undiagnosed bilateral anterior shoulder dislocation after a seizure: a case report. 
Cases J 2008;1:342.

2. Cresswell TR, Smith RB. Bilateral anterior shoulder dislocations in bench pressing: an unusual cause. Br J Sports Med 1998;32:71-2.

3. Prillaman HA, Thompson RC Jr. Bilateral posterior fracturedislocation of the shoulder. A case report. J Bone Joint Surg [Am] 1969;51:1627-30.

4. Gosens T, Poels PJ, Rondhuis JJ. Posterior dislocation fractures of the shoulder in seizure disorders--two case reports and a review of literature. Seizure 2000;9:446-8.

5. Dinopoulos HT, Giannoudis PV, Smith RM, Matthews SJ. Bilateral anterior shoulder fracture-dislocation. A case report and a review of the literature. Int Orthop 1999;23:128-30.

6. Betz ME, Traub SJ. Bilateral posterior shoulder dislocations following seizure. Intern Emerg Med 2007;2:63-5.

7. Sanjay M, Pramod S, Vivek S, Ramakant K, Vivek T. Bilateral anterior shoulder dislocation. J Nat Sci Biol Med 2013;4:499-501.

8. Sahin N, Oztürk A, Ozkan Y, Atıcı T, Ozkaya G. A comparison of the scapular manipulation and Kocher's technique for acute anterior dislocation of the shoulder. Eklem Hastalik Cerrahisi 2011;22:28-32.

9. Büker N, Kitiş A, Akkaya S, Akkaya N. Artroskopik yardımlı mini-açık yöntem ile rotator manşet tamiri yapilan hastalarda fizyoterapi programı ile ev egzersiz programının sonuçlarının karşılaştırılması. Eklem Hastalik Cerrahisi 2011;22:134-9.
10. Brotzman SB, Mantske RC, Daugherty K. Clinical Orthopaedic Rehabilitation. 3rd ed. Philadelphia: Elsevier; 2011. p. 106-13.

11. Yanmiş I, Kömürcü M, Oğuz E, Başbozkurt M, Gür E. The role of arthroscopy in chronic anterior shoulder dislocation: technique and early results. Arthroscopy 2003;19:1129-32.

12. O'connor-Read L, Bloch B, Brownlow H. A missed orthopaedic injury following a seizure: a case report. J Med Case Rep 2007;1:20.

13. Purchase RJ, Wolf EM, Hobgood ER, Pollock ME, Smalley CC. Hill-sachs "remplissage": an arthroscopic solution for the engaging hill-sachs lesion. Arthroscopy 2008;24:723-6.

14. Kalkan T, Demirkale I, Ocguder A, Unlu S, Bozkurt M. Bilateral anterior shoulder dislocation in two cases due to housework accidents. Acta Orthop Traumatol Turc 2009;43:260-3.

15. Bühler M, Gerber C. Shoulder instability related to epileptic seizures. J Shoulder Elbow Surg 2002;11:339-44.

16. Hutchinson JW, Neumann L, Wallace WA. Bone buttress operation for recurrent anterior shoulder dislocation in epilepsy. J Bone Joint Surg [Br] 1995;77:928-32.

17. Connolly JF. Humeral head defects associated with shoulder dislocations: Their diagnostic and surgical significance. Instr Course Lect 1972;21:42-54

18. Tripathy SK, Sen RK, Aggarwal S, Dhatt SS, Tahasildar N. Simultaneous bilateral anterior shoulder dislocation: report of two cases and review of the literature. Chin J Traumatol 2011;14:312-5. 